\title{
PROPOSALS FOR AN INTERNATIONAL COURT
}

In the course of the progress that has been made towards international organization, many proposals have ben offered for an international tribunal. No man's scheme for such a court can be said to be famous in the popular meaning of that term, bist certain projects are more or less familiar to students of the movement for arbitration. An account of some of these with extracts from their texts, is given in Dr. Darby's compendious work on "International Tribunals". It is interesting from the point of view of the constitution, functions and sanctions of an international judiciary, to compare certain of the characteristics of these plans with the Hague Court of Arbitration, the International Prize Court, or, more particularly. with the proposed Court of Arbitral Justice.

The so-called "Grand Design" of Henry the Fourth of France, 1603 , looked toward the division of Europe among fifteen powers "which would have nothing to envy one another for on the ground of equality, and nothing to fear on the ground of balance of power". The model for the organization of these States, which was to have a general council, was that of the Amphictyons of Greece. The council was to consist of commissioners, ministers, or plenipotentiaries from all the powers, who, sitting as a senate, were to deal with the different interests brought before them an 1 to pacify quarrels. There was also to be a system of minor councils with the right of appeal to the Great General Council. . The decrees of this body which were conceived as emanating from the united authority of the sovereigns were to be irrevocable and unchangeable. They were also to be supported by military force, which was to be contributed and maintained by each power in the Confederation. Disputes arising over the readjustments of the European nations, according to the proposed plan, were to be referred to the arbitration of the Kings of France, England, Lombardy and the Republic of Venice. Disagreements over the election of the Emperor or the Kings of the Romans were to be referred "to the arbitration of the Pope, the Kings of England, Denmark, and Sweden, of the Venetians and the Cantons of Switzerland, such of the three as they should wish to choose". The objects of the "Grand Design", although related to the establishment of peace in Europe, were primarily intended to reduce 
the influence of the House of Hapsburg, which at that time predominated, and were therefore quite as political as they were pacific.

The plan of Eméric Crucé, who was born in Paris, 1590, and died in 1648, contemplated the formation of a Universal Union embracing even China and the Indies, having a Congress of Ambassadors, who should meet in such a city as Venice where all the sovereigns regularly maintained diplomatic representatives. An ambassador could there plead the grievances of his master, while his colleagues could jugdge without prejudice the case he presented. Failure to abide by the award would mean the disapprobation of the princes who were expected to find suitable means to bring recalcitrants to reason.

The plan of William Penn for a European Diet, Parliament, or Estates, 1693-94, although not a reproduction of the "Grand Design," was doubtless influenced by it. William Penn's plan proposed a union of the States of Europe for the purpose of promoting peace and order, chiefly through a periodic congress, which was to be empowered to settle disputes between one sovereign and another whenever they could not be adjusted previously by diplomacy. In case of the refusal of a state to submit its claims or pretensions to a diet, or to accept a judgment of that body, compliance was to be enforced by the united military power of the confederation; while, as a further penalty, damages to the suffering party and charges incurred by the sovereigns that were obliged to reduce the disobedient state to submission might be exacted.

The plan of Abbé de St. Pierre, 1658-1743, was a philosophic amplification of the plan of Henry the Fourth. It provided for a union of European nations, and contemplated drawing into it sovereigns of Asia. This plan included in its scope a congress or senate of deputies, who were supposed to be chosen for their pacific temperament and might be dismissed if they did not manifest it. They were to have a regular residence in a place called "The City of Peace", which was to be fortified against capture. The whole body of senators were to be assisted by a special executive council of five of their own number and by other committees, some of which were expressly formed to reconcile the differences between the states. The General Assembly was to exercise arbitral functions. A sovereign against whom an award was given, was supposed to execute it himself, but a united force 
under a generalissimo might, in case of disobedience, be empowered to compel submission. An arbitral judgment was first to be pronounced provisionally by a majority vote, and six months afterwards definitively by a three-fourths majority vote. Thus there were to be two judgments on every dispute.

John Bellers, 1710, who, like William Penn, was a Friend, wrote a treatise in which he reproduced Penn's plan in substance and made an analysis of the "Grand Design" of Henry the Fourth. Leibnitz, 1646-1716, was conversant with the plans of Abbé St. Pierre and Henry the Fourth, but although identified with arbitration, threw little or no light upon the subject of a court.

Rousseau, 1712-1778, made a study of the social, legal, and governmental advantages of peace, conceiving a transition from the voluntary society of European states to a solidified political confederation to be desirable. This confederation was to be an irrevocable alliance of sovereigns with a permanent diet, in which all differences should be ended by arbitration or judicature. The contracting powers were to give mutual guarantees of political rights and of territory, based upon conditions then prevailing, an arrangement which the author believed would coniluce to perpetual peace. If, however, a state should violate the constitution or refuse to obey the judgments of the confederation, it was to be put under the ban of the rest of Europe. The other states were then to act as a unit in declaring and waging war upon it even to the point of repairing wrongs and exacting costs.

Like Rousseau, Kant in his "Perpetual Peace", proposed a republican confederation of European states, agreement to enter which, however, should be revocable. The confederation was to act through a permanent international congress. Speaking as a philosopher rather than a jurist, Kant, in this study, made no explicit provision for a tribunal, but he believed in settlements by law instead of war, and required the abolition of standing armies.

A glance at these plans will show us that they are of interest to the antiquarian rather than to ourselves, as they are of little assistance in the problems of toclay. As a rule, they were confined to Europe, whereas our vision takes in the world; and where they offered anything like a court, it was combined with a Congress of Nations, the legislative and judicial functions being practically in one department. This arrangement is contrary to our present day conception of international juridical organization. 
It was not until the nineteenth century that we began to have a very clear idea of the necessity of the separation of the judicial from the legislative functions in schemes for an international court. This separation of powers, which is familiar enough to a student of American institutions, or of Locke, or Montesquieu, William Ladd made very plain in his essay on a Congress of Nations, 1840. His idea was to have both a congress of nations and a court of nations; the Congress to prepare a code, and the court to administer it. Mr. Ladd proposed that the nations should have equal representation on the tribunal and suggested that two judges be appointed from each of the governments represented in the Congress. These judges were to have advisory power only; to take cases brought to them by mutual consent, as a chamber of commerce, and to give their decisions without sanction of international police or sheriffs. So far as sanctions are concerned, we have not advanced today much beyond the principle of advisory arbitration, a proceeding that is applicable to absolutely free and independent states. The sanctions of arbitration are moral, not physical, being based on the good faith of the litigants and the compulsion of public opinion. The judges of Mr. Ladd's court were to have a tenure to be agreed upon by the governments, notably during good behavior. The judges were to be paid either by the governments sending them or by the governments in Congress conjointly, according to the ratio of their population or wealth. According to the practice of the Permanent Court of Arbitration, the judges are paid by the litigant governments in equal moieties through the Bureau of the Court; while by the scheme of the Court of Arbitral justice, the judges are to be paid by the whole body of the contracting states which establish the court, the assessments being the same for each of them. Mr. Ladd's suggestion of a proportionate assessment may yet be considered for the Court of Arbitral Justice. We find a plan for proportionate assessment in the convention for the International Prize Court, it being stipulated that the expenses of that court shall be borne by the contracting powers in proportion to their share in the composition of the court. Mr. Ladd's court was to organize itself by choosing its president and vice-president, from its members, and they were to select clerks, secretaries, and reporters. The provision for an official staff of the court has 
already been carefully worked out for us today in the scheme of the Permanent Court of Arbitration, for which there is provided an Administrative Council, together with a permanent bureau which has a secretary and subordinate officers. These officials of the bureau may be utilized by the Prize Court or the Court of Arbitral Justice when instituted.

The procedure outlined by Mr Ladd really amounted to very little. He suggested, however, that both sides should be heard and made a few other sound recommendations. It is an interesting fact to the friends of the Court of Arbitral Justice, that. he proposed that his court should meet. once a year, a coincidence with the scheme for the Court of Arbitral Justice, which provides for an annual session beginning the third Wednesday in June; but $\mathrm{Mr}$ Ladd stipulated that the court should never meet in the country which had a case on trial. In his time, however, no single national capital or place for the sitting of an international court had been agreed upon. Its location was a matter to be determined. in the future. The members of the court were to have the protection afforded by diplomatic imminity, as is the regulation of today. Awards were to be made by a majority vote; as has long been the custom with arbitration tribunals. A written opinion prepared by one of the judges was to be given upon the conclusion of a hearing. Written opinions are also contemplated by the projects of the International Prize Court and the Court of Arbitral Justice, and have been given in cases settled by the Permanent Court of Arbitration.

The judges, in making a decision, were to be governed by treaties in force between the parties or by the laws made and ratified by the International Congress, as, for example, the code; and if the arbitrators could not be guided sufficiently either -by treaties or by the code, they should judge by the principles of equity and justice. These provisions are similar to the arrangement in the International. Court of Prize, which might be adopted for the Court of Arbitral Justice.

In case of disputed boundary, the parties were authorized to appoint special surveyors, or commissioners, at their own expense. Compare this with the use of a delegation of judges to. serve as an international commission in the scheme for the Court of Arbitral Justice.

As to jurisdiction, the court was to determine controversies brought before it voluntarily, but it might, apparently on its own 
initiative, exercise offices of mediation. If a difficulty were impending which threatened war, or if a war were in progress, the court might serve as a good angel to bring the trouble to an end.

Mr. Ladd also provided in his scheme that internal disputes within a nation might be brought before the court, as, for example, the case of a dispute between two rival claimants for a throne. Such disputes he thought might be decided by the law of the country in which the dispute had arisen; but although the court might propose terms of reconciliation, it should never give an ex parte verdict.

Under the Hague peace system, mediation is exercised by one or more friendly powers, who bring their influence directly, to bear upon the governments which are at odds; but the neutral powers collectively may, through the Bureau at The Hague, remind the parties that the Permanent Court is open to them. But in no instance under the Hague system are judges expected to act as mediators, and it was one of the objects of those who proposed the Court of Arbitral Justice to have a tribunal which should be absolutely without diplomatic functions. Even the temptation to compromise in making a decision was condemned. Diplomats acting as arbitrators were considered, as it were, the bane of arbitration; for them it was the intention to substitute men acting under a sense of judicial responsibility, If, therefore, Mr. Ladd separated the judiciary from the congress, the framers of the Court of Arbitral Justice have eliminated diplomacy in every form from the judiciary. This is one of the key notes to the movement for the judicial settlement of international disputes. Diplomacy is properly an executive function.

Mr. Ladd also suggested that the court might propose for the consideration of the Congress such new or unsettled principles favorable to the peace and welfare of the nations as might present themselves during the trial of cases. We today hesitate to give an international court any more power than to suggest new rules of procedure, and we make them subject to reference to the governments, but in the International Prize Court and the Court of Arbitral Justice we contemplate the development of law by judicial precedents.

The work of the two Hague Conferences was foreshadowed more directly by William Ladd than by any other publicist; but he also thought that after the international congress had done with measures for the prevention of war, its regulation and the 
rights and duties of neutrals, other legislation should be made for the general welfate of the nations.

Mr. Ladd's underlying theory of the value of an international court is substantially the same as ours, that a nation would not be justified by public opinion in going to war if there were an impartial tribunal to judge its case. He believed that many disputes would be quashed at the outset if the parties knew that the point disputed was likely to become the subject of an impartial investigation by able judges. Mr. Ladd's plan was a work of genius. It was truly far sighted in its conception, quite up to our own time in some particulars and ahead of it in others. It had few defects. Though lacking in procedure, it is otherwise the most symmetrical of any of the nineteenth century projects for an international court.

Another proposal bears the name of James Mill. It was dated 1825 , and therefore preceded by fifteen years that of Mr. Ladd. Mr. Mill, like Mr. Ladd, proposed both a code and a tribunal. Following the spirit of early Roman custom, he suggested a tribunal of one man, who, as a case came up, should be especially selected for his qualifications from and by a board of judges. These were to be trained men previously chosen from different countries upon the basis of the equality of the nations, each of which was to appoint one member of the judiciary. The judge was to try his case in the presence of all his colleagues, who were to be allowed to express their opinions. He was also to be under the responsibility of having present at the trial the judges appointed by each of the two contending parties. The presence of the whole body of neutral justices, Mr. Mill reasoned, would encourage the diligence, fairness, and honesty of the trial judge; while the watchfulness of the delegates of the litigating parties would ensure that the merits or demerits of his conduct would be made known to the world. Mr. Mill also proposed that three classes of cases should be brought before the tribunal: voluntary cases; cases in which one nation appears but the other refuses to appear; and cases in which both nations ought, but refuse to àppear. If one nation refused to appear, that fact was to be taken as evidence against that nation, and if both nations failed to appear, the court was to go on to a decision with such an understanding of the dispute as it could gather from such direct and circumstaritial evidence as was in its possession. The family of nations was not to be allowed to suffer because the parties to the dispute refused to come to court. 
Mr. Mill, like Mr. Ladd, did not sanction international police, but proposed moral sanctions, among which, for example, is the denial of certain rights of ceremony to a recalcitrant nation, such as putting the nation last of all instead of in its right place, ur denying to its citizens certain benefits of the law, that are granted to other foreigners; such as not allowing them to sue in the courts except in regard to the higher crimes or the more serious violations of person or property. In speaking of the case in which both nations failed to respect the jurisdiction of the court, he said: "A decision solemnly pronounced by such a tribunal would always have a strong effect upon the imaginations of men. It would fix, and concentrate the disapprobation of mankind. Such a tribunal would operate as a great school of morality." $\mathrm{He}$ also believed in full publicity being given both to code law and to the decisions of the court, even to carrying knowledge of them into the schools, thus systematically educating as well as invoking the sanction of public opinion.

Jeremy Bentham had, in an essay on International Law; written 1786-89; proposed only as a last resort, putting a recalcitrant under the ban of Europe, believing that an international court that was without coercive powers would facilitate permanent peace, and that there would probably be sufficient sanction if, in the constitution of the court, there were inserted a clause guaranteeing the liberty of the press in each state so that the widest possible publicity to decrees might be given.

John Stuart Mill, without proposing a scheme for an international court, outlined in his Representative Government, the functions of a federal supreme court which should be organized very much like the Supreme Court of the United States; emphasizing the fact that such a court implied a federation not only of the states, but of their people. Following the spirit of the Constitution of the United States, he added a plan for subordinate courts. Such an adjunct is now being proposed by some American jurists for an international judiciary, of which the Court of Arbitral Justice would form the supreme bench and could, like the Supreme Court of the United States, be utilized for cases of appeal.

Professor J. R. Seelye (1870) believed in a court entirely different from a congress or concert of European powers. He held that an ambassador could not be a good judge; that there must be a distinctly created law court. He thought that an international law court implied naturally a federation of nations and 
plainly said what many American jurists hesitate to say, that "we have a problem of federation before us and not merely the constituting of a law court". As a state is implied in a law court and gives it character and efficiency, so "an international law court implies an international state". He deemed it to be necessary for ten states of Europe-he was not thinking of the world - to organize a federation and have a congress which should execute the decisions of the court. He proposed dividing the powers of the federation into legislative, executive, and judicial, as in the Constitution of the United States. He thought the federation should have an independent executive of its own, through which authority must be brought to bear upon individuals, who should have obligations to the federal state as citizens-the Amer: ican theory. "All federations," he said, "are mockeries that are mere understandings between governments." He stated that there was but one substitute for war, that was to refer a dispute to a third party, and then to impose its decision upon the contestants with everwhelming force. "The last step. in this process, the power of enforcing the decisions by the federal union only," he added, "is just as essential as the earlier ones, and if you omit it you may just as well omit them, too." In other words, you must have with an international federation, an international police. The history of international arbitration, however, as confined to the established voluntary basis, in which nations agree to submit their disputes to an arbitration, does not, as Dr. Darby points out, justify the institution of police as a sanction, there having been no case in which force has had to be employed to compel obedience to an arbitral decision, which, by implication, if not formally, the parties bind themselves to carry out in good faith.

David Dudley Field, 1872,.proposed as a part of his project for a court a code very explicitly made. If a controversy arose that nations could not settle, there should be formed a joint commission of inquiry which should consist of five men from each contesting nation, who were to meet, discuss differences, try to reconcile them and within six months make a report, each group to its respective government. If the commission, which resembles the international commissions proposed by the United States today, could not agree upon a solution of the dispute, or the parties should fail to ratify the acts of their commissioners, the difference was then to be referred to a high tribunal of arbitrition 
consisting of seven judges. These were to be chosen from a list of four appointees each from all the other nations that adopted the code. The list was to be handed to the parties in the controversy within three months after notice of disagreement, and they, by process of elimination, were to choose the board of arbitrators. Mr. Field believed in having a conference of representatives of all nations, every year on the first of January, at the capital of each nation in rotation, to discuss and amend the code, avert war, facilitate intercourse and promote peace.

Mr. Field's method of selecting a tribunal may be compared to that in use under the system of the Permanent Court of Arbitration, which provides a list of four appointees or fewer from each nation in the conference at The Hague. There has been no instance at The Hague, however, in which as many as seven arbitrators have been used. The difficulties as to the choice of arbitrators, whether by a process of elimination or otherwise, are obviated both in the Prize Court and the Court of Arbitral Justice, the projects for which provide permanent tribunals.

Sir Edmund Hornby proposed a court whose members were to have a ten-year term, during which they should be freed from allegiance to any state. These men should have high social rank with commensurate salaries and pensions. They should therefore be in a position to receive and maintain the just respect of the world. They should be nominated by the governments, but should not represent them or be their mouthpieces in any sense. The tribunal, when formed, should consist of not less than thirteen members, "not necessarily jurists by profession, but states'men and diplomatists, or men who have filled judicial offices" Stress is now being laid on the qualifications of arbitrators as jurists or professionally trained judges. Here, however, we have emphatically stated that principle of independence of national influence which we find in the plans for the International Prize Court and the Court of Arbitral Justice, but which is less carefully guarded in the plan of the Permanent Court of Arbitration, the arbitrators in that court being under comparatively easy restrictions. The national or representative characteristic of arbitrators has in the past sometimes made an arbitration seem more like an adjustment by diplomatists, each thinking of his own country's interests, than a decision by impartial jutges deciding upon principles of international law. And we may compare Sir Edmund's proposed ten-year term for the judges of his court 
with the twelve-year term for the judges of the Court of Arbitral Justice, his tribunal of thirteen with the proposed tribunal of seventeen. The terms of the judges of the International Prize Court and the Arbitration Court are six years.

James Lorimer, in 1884, in his "Institutes of International Law" (Vol. II, 181), discussed at length "The Ultimate Problem of International Jurisprudence", in which he gave abstracts of various plans for courts, and presented a project of his own ( $p$. 279). He proposed an international government with legislative, judicial, executive, and financial departments. His judicial tribunal consisted of a criminal and a civil branch with life appointments. He advocated "fourteen judges and a president, six of whom shall be chosen at least from six great powers, one from each". Questions within the competence of the court were to be brought before it voluntarily or remitted to it by an executive bureau or ministry. He provided for an international attorneygeneral and an international bar.

Many of the projects for an international tribunal in the early periods were simply methods for use as needed, and the tribunals were to be erected only after a controversy between two nations had come up. There was no standing list of arbitrators such as we have at The Hague today. Several propositions for tribunals go chiefly into details of procedure, and are arbitral systems rather than proposed constitutions for courts, such as the project of William Ladd, with which they may be contrasted. For thoroughly elaborated projects of this kind, see those of Professor Corsi and Professor Fiore in Darby's "International Tribunals".

Usually where tribunals are proposed, the number of arbitrators is three, five, or seven. The third, fifth, or seventh member is chosen by his colleagues, who are authorized to meet and elect an umpire or president. Sovereigns, a state, a township, a réligious authority, a faculty of law, a learned society, or the actuäl head of one of these bodies as well as jurisconsults and publicists have been recommended and in some cases actually employed as arbitrators. Contrary to former custom, neutrails rather than nationals are preferred by some jurists, as judges, notably by Jackson H. Ralston, who has spoken forcibly on this subjët before the American Society for Judicial Settlément of Intèrnational Disputes in $1910^{\circ}$ and 1913.

For examples of arbitral tribunals erected by the United States and Great Britain, we may turn to the Jay Treaty, 1794; the 
Treaty of Ghent, 1814; the Fisheries Treaty, 1854; or the treaty of Washington, 1871. The latter treaty in arranging for the tribunal which met at Geneva, provided for one national each to be chosen by the President and the Queen, and three neutrals to be chosen by the. King of Italy, the. President of the Swiss Confereration, and the Emperor of Brazil. The tendency nowadays is for the litigating governments themselves to choose all the arbitrators, which in important cases are usually selected from the list of members of the Permanent Court of Arbitration at The Hague.

Among other tribunals erected by the United States and Great Britain may be mentioned the tribunals constituted to settle questions relating to the Behring Sea 'Fisheries under convention of February 29, 1892, Behring Sea Claims under convention signed February 8, 1896; Alaskan Boundary, under convention signed January 24, 1903; and the North Atlantic Fisheries, settled at The Hague under special agreement, signed January 27, 1909. An arbitration of of pecuniary claims was arranged under agreement signed August 18, 1910. A treaty between the United States and Great Britain respecting the boundary waters between the United States and Canada was signed January 11,1909, which was intended to prevent disputes regarding the use of boundary waters, to settle all questions relating to the frontier and to make provision for the settlement and adjustment of all such questions as might thereafter arise between the governments or their inhabitants. The latter arrangement provides for a standing joint international commission of six men, three of them appointed by the President and three by the King, on the recommendation of the Governor in Council of Canada. The commission is to examine and report with recommendations in ordinary cases, but may be empowered to decide a question that is expressly referred to it for decision: by the two governments. In event of disagreement provision is made for the appointment of an arbitrator.

The unratified Olney-Pauncefote Treaty of 1897 ought to be examined for its applicability to British and American conditions, when, for any reason, reference to The Hague may be undesirable. This treaty provided different kinds of tribunals, to consist of three, five, or six members for different classes of cases, according to their relative pecuniary importance, or their character. Territorial claims or grave questions affecting national as distinguished from individual rights, in. which the nation ap- 
peared only as an international representative, were to be adjudicated by six judges to be chosen by the President from the Supreme Court or Circuit Court of the United States or by the Queen from the British Supreme Court of Judicature, or the Judicial Committee of the Privy Council. If a decision was rendered by less than a majority of five out of six and was protested, or the tribunal was equally divided, it was stipulated that there should be "no recourse to hostile measures of any description until the mediation of one or more friendly powers has been invited by one or both of the High Contracting Parties". The proposal for resort to mediation is a good safeguard.to attach to a treaty of arbitration.

A carefully wrought out scheme for the organization of a European Federation, by .Dr. J. C. Bluntschli, will be found in Darby's "International Tribunals" (page 194). In the opinion of this distinguished writer, the execution of decisions should usually, be left to the discretion of the various states; but if compulsion should be necessary, he favored the coopperation of the Great Powers in the exercise of forcible pressure. He thought that on the whole a constitution providing guarantees for a just settlement of all disputes would render actual compulsion practically unnecessary and make wars rare in the future. 'Lorimer, in speaking of Dr. Bluntschli's plan, says that this great jurist and Henry the Fourth stand by themselves in proposing a universal state in contrast with Kant and others who go only so far as to propose a confederation. There are, however, a few other great writers who believe that a federation is likely to be the ultimate form of world organization.

Among other suggestions for courts of arbitration which will be found in Dr. Darby's collection, the following are worthy of especial attention: Sprague's High Tribunal of Public International Judicature; the Peace Congress "Code of International Arbitration"; Arnaud's Model of a Treaty; Rules of the Institute of International Law; Proposed Rules of American Jurists; the Memorial of the New York Bar Association; the Scheme of the Inter-Parliamentary Conference; Arbitration Tribunals; a thorough exposition by Dr. Darby; the Brussels Rules of the International Law Association; and the Buffalo Rules of the International Law Association. The Pan American arbitration system proposed in 1890 and 1902 ought also to be examined.

Charles Lemmonier, in drafting a form of an International 
Treaty, put in what is in effect a bill of rights for the protection both of states and individuals, a precaution that will probably be considered at some future day at The Hague Conferences. The present declaration of principles in the preamble of the Convention for the Pacific Settlement of International Disputes is a beginning.

The memorial of the New York Bar Association (1896) which is frequently mentioned in the history of the agitation for an international court, proposed a tribunal of nine members, "one each from nine independent states or nations, such represéntative to be a member of the Supreme or Highest Court of the nation he shall represent, chosen by a majority vote of his ássociates, because of his high charācter as a publicist and judge, and his recognized ability and irreproachable integrity: Each judge thus selected to hold office during life or the will of the Court selecting him". This method of choosing international judges by members of high national courts, when proposed at the First Hague Conference, was found to be impracticable, as European courts, especially the high court of Germany, were unfitted by their limited acyuaintance with the great body of jurists to make a wise choice for a judiciary. This court which wàs to be called "The International Court of Arbitration", was to have jurisdiction over all disputes arising between the powers that cotild not be adjusted by friendily negotiations. It was to be opened to other powers than the nine that might initiate it, to be accessible at all times, to fix upon its place of sessions, make its own rules and appoint its own clerks. It is needless to say that this plan is for the present amply covered by the projects of courts already adopted at The Hague and particularly by the draft of the Court of Arbitral Justice which requires specially trained judges.

In 1895 we find a scheme proposed by a committee of the Interparliamentary Union that in some respects resembles the plan adopted by the Permanent Court of Arbitration at The Hague. This court was established in 1899 by the First Hague Conference. By the agreement every contracting power was allowed to select "four persons at the most of known competenicy in questions of international law, of the highest moral reputation, and disposed to accept the duties of arbitrator" The names of these men were to be inscribed at The Hague on a permanent list of available judges. Two or more powers were permitted to agree on the selection in commori of one or more members and it was 
allowable for the same person to be selected for different powers. From this list two or more nations, that are involved in a controversy may select such a tribunal as they desire, whether it consists of three or five, ar even more, members. If five members are chosen it is expected by the rules adopted in 1907 that three of the members, including the president, shall be neutrals; but there may be one national or permanent appointee of each of the contending parties. Five arbitrators, were chosen according to this arrangement for the Fisheries. Tribunal. For cases of summary procedure, a provision for which was made in 1907 , three judgess were proposed. A sovereign or chief of state may act, as was customary in times past; and he may fix his own procedure, But. ordinarily the outline of procedure that is furnished by the convention is expected to be followed. A more practical code of procedure, however, has been recommended for future adoption by William C. Dennis and Robert Lansing.

A draft of the Court of Arbitral Justice was adopted in principle by the Second Hague Conference in 1907. The number of judges is not distinctly given; but in the discussions fifteen to seventeen were suggested. Seventeen were provided for in a rota plan that was published in the proceedings of the conference. As large a number of judges as fifteen or seventeen, however, may be so many as to be unwieldy and expensive; seven or nine have been proposed as a better number to begin with.

The International Prize Court, a court of appeal fur cases of prize, or of first instance if there has been two years delay by the courts of a captor nation, was instituted in 1907, but remains unratified by nearly all the nations. It is expected that when it is put into operation its decisions will be governed chiefly by the Declaration of London, which was adopted by some of the leading maritime powers in 1909. As in the Court of Arbitral Justice, the judges must be professionally qualified for their duties.

The Permanent Court of Arbitration at The Hague may be distinguished from the International Prize Court and the Court of Arbitral Justice by the fact that it is a list of names from which a tribunal is chosen, for a case as it comes up; while the new courts are both intended to have a permanent body of judges capable of acting as a full bench. The Prize Court justices are to be summoned and paid for the trial of prize cases as they occur, while the members of the Court of Arbitral Justice who have a yearly salary of about $\$ 2,400$ besides per diem pay and 
travelling. expenses while in actual session, are to meet in annual session on the third Wednesday in June, unless utter lack of cases makes their meeting unnecessary. These justices may also be called in extraordinary session if necessary.

The provision that is made for a permanent delegation of three members to serve between sessions is a feature of the Court of Arbitral. Justice that is sometimes minimized, but it would seem to be of practical value. The delegation is intended primarily, though not necessarily, for minor cases. States in litigation may add to the delegation a national each, making a tribunal to consist of five members. Here we have a coincidence with some of the tribunals of the past and with the practice of the Permanent Court of Arbitration, the number of judges on tribunals having varied from three to five.

Đr. A. F. de Savornin Lohman, who, like many Europeans, is understood to favor the present Court of Arbitration, of which he himself has been an illustrious member, says that the best kind of a tribunal consists of three men only, all of them of course neutrals; yet he believes that the presence of national members in the International Court is of great importance, and suggests one for each of the contending parties. In explaining his belief in the use of nationals, he says: "In the first place, because however well-informed the arbiters may be by the counsellors of the litigating parties, information is necessary during the deliberations, which may be easily furnished by the national possessor of the same, naturally only information with regard to facts in confesso, but which may elucidate the judge's discrimination and tend to a good and appropriate judgment. Secondly because their presence ensures a serious and all-round consideration; which is the more to be desired when the deliberations are not public. It is on these grounds that $I$ am of the opinion that each of the litigating parties should appoint a most efficient compatriot to attend the treatment of the affair throughout, with the same qualifications as the other judges, except that of taking part in any decision."

The chief difference between the use of the delegation of the Court of Arbitral Justice and the total board of five judges advised by Dr. Lohman is in the question of allowing the nationals to vote. By the draft of the Court of Arbitral Justice they are allowed a vote; by the proposal of Dr. Lohman, they are not. If the proposition of Dr. Lohman for addition of nationals is 
correct, would it not be possible by compromise to alter in the matter of voting the draft of the Court? In any case, it would seem that the advocates of the Court of Arbitral Justice ought to emphasize more than they have emphasized the use of the delegation. Its permanence is an absolutely unique and vital feature of that court. It ought to be comparatively inexpensive. The cost of keeping three men in permanent residence at Thie Hague would be inappreciable; the expense would be met conjointly by all the nations that establish the court and would not fall heavily upon any two litigants. The cost of a litigation under the present system, which is borne by the parties, discourages reference to the Court of Arbitration.

The convention for the Arbitration Court recognizes the equality of nations in the methods of choosing arbitrators for the tribunals of that court; both litigants being given equal rights in the choice of judges, a fact which helps to make that court acceptable to small and large nations alike. The Prize Court by its rota system, however, fails to recognize the equality of nations, for judges of some'powers serve all the time, while judges of other powers take turns. Whether or not rotation will finally be the fashion with the Court of Arbitral Justice, remains to be seen; but the attempt made at the Second Hague Conference to. constitute a tribunal for this court on the rota plan, based on population, material interest, difference in judicial system and language, was unsuccessful; the question of the appointment of judges was left to future negotiations.

The Prize Court is the only 'one of these three institutions projected at The Hague that has its jurisdiction definitely fixed by the international convention that creates it. Cases are to be brought before the other courts by special agreements, by treaties, or, according to the draft of the Court of Arbitral Justice, by " a general undertaking". It will be remembered that all these courts may utilize the permanent bureau and official staff already established. An arrangement for a bureau is often lacking in earlier projects of courts before the Hague Conferences were held.

An advantage of both the Prize Court and the Court of Arbitral Justice that marks an advance upon. the Permanent Court of A'rbitration and the ad hoc tribunals that have formerly been constituted under treaties, or in some instances proposed by jurists, is that the very permanence of the personnel of these new courts ensures development and continuity of jurisprudence. 
None of the Hague Courts, however, provides for the use of military force or boycott as a sanction; for compliance with the terms of an award they depend upon the good faith of the litigant nations, which, as already indicated, practically agree in advance to accept the decision of the tribunal before which their case is brought. A few penalties, such as loss of rights of inviolability, personal punishment, indemnification for losses, or liabilities to a law suit, are prescribed in case of the violation of the rules of war; ; and each government is expected to enforce for itself the rules of neutrality when they are violated. The courts of The Hague, therefore, differ radically from the schemes of several of the famous worthies of the past, who provided other than moral sanctions to support legal decisions. Although various nations may by treaty obligate themselves to arbitration, they are not expressly made liable to physical compulsion; the obligation assumed being moral only. The Porter-Drago convention implies that force may be used only when an offer to arbitrate has been declined or left unanswered, or having been acceeded to, participation in the drawing of the terms of the compromise is refused, or if there is failure to comply with an arbitral award, once it is rendered. States under the present Hague system are not formally cited before the court, nor may they be dealt with ex parte, as was suggested, for example, by James Mill. One country may, however, be notified through the bureau that another is willing to arbitrate a given case. The International Prize Court implies a more automatic arrangement for coming before the court than is found either in the Permanent Court of Arbitration or the plan for the Court of Arbitral Justice.

All the courts connected with The Hague relate more or less to the Convention for the Pacific Settlement of International Disputes, which provides a system of mediation and of international commissions of inquiry to be used as an adjunct to the court if desired, but to be instituted through diplomatic means, and not to be operated by the courts, except that a provision is made for use of the delegation of the Court of Arbitral Justice as a commission. As the Hague system is developed, there will probably be a complete code of international law. Besides legislation for courts, there are now codes relating to the regulation of war and -neutrality. There will probably also be a periodic congress and an executive officer or commission, for which latter the Administrative Council of the Court at present serves. 
The Permanent Administrative Council is composed of diplomatic representatives of the contracting powers accredited to The Hague and of the Netherlands Minister for Foreign Affairs, who is its president. This officer, on behalf of the society of nations, received from the Committee of the Carnegie Foundation, the custody of the Palace of Peace, which was dedicated August 28, 1913, as the permanent home of the international court.

The Central American Court of Justice, formed in 1908, and therefore after the Second Hague Conference, is neither a draft of a proposed tribunal nor a convention awaiting general ratification, but is an institution that is already at work. It is appropriately called a Court of Justice, and not a Court of Arbitration. It avowedly provides for the settlement of international disputes without resort to war by the powers that are parties to its establishment. It has a tribunal of five professionally qualified justices, one chosen from each state, together with two substitute judges from each state, all. of them appointed at the same time for terms of five years. Five justices must always be in attendance to compose a legal quorum. Regular or substitute justices while in service are not supposed to hold any other public office, or to practice law. They are paid a salary of $\$ 8,000$ a year. Every one of the five Central American governments contributes an equal part towards the maintenance of the court. It will be remembered that the plans for the Court of Arbitral Justice and the International Prize Court provide for substitute or deputy judges.

The jurisdiction of the Central American Court of Justice covers "all controversies or questions which may arise" among the Central American States "of whatsoever nature and no matter what their origin may be, in case the respective Departments of Foreign Affairs should not have been able to reach an understanding". The court takes cognizance not only of cases between the Central American states themselves, but cases in which these states and foreign governments are interested and which both parties are willing to submit to the tribunal. The agreement establishing the court furthermore says: "This court shall also take cognizance of the questions which individuals of one Central American country may raise against any of the other contracting governments, because of the violation of treaties or conventions, and other cases of an international character; no matter whether their own government supports said claim or not; and provided 
that the remedies which the laws of the respective country provide against such violation shall have been exhausted or that denial of justice shall have been shown." This court also has faculative jurisdiction over cases between the contracting governments and individuals when by common accord, such cases are submitted to it.

We may compare the absolute rights of litigation enjoyed by an individual under the agreement for the establishment of the Central American Court of Justice with privileges of appeal granted an individual under the scheme for the. International Prize Court when the judgment of a national tribunal injuriously affects his property. 'A neutral may be forbidden by his government to bring his case before the International Prize Court, but an individual subject of an enemy government may frely apply to the Court when the judgment relates to a cargo on board a neutral ship or is contrary to a convention in force between the hostile powers or an enactment issued by the belligerent captor. But it is significant that in the Central American Court and the International Prize Court an individual may go before an international tribunal without the customary intervention of his government. Some European writers propose that a freer jurisdiction than there now is over cases of claims of citizens against governments be established at The Hague. The need for such a jurisdiction or for a more practical system, as advocated by American writers may be traced in the proposals of Mr. Everett P. Wheeler before the American Society of International Law (1912), and Mr. Edwin M. Borchard before the Lake Mohonk Conference on International Arbitration (1913). There is also a tendency on the part of Europeans for the institution of a jurisdiction at The Hague for cases of private international law, but this is not fully shared by Americans owing to differences between.American and Continental juridical theories.

Such in general is an outline of some of the plans that have been proposed or are already adopted for international courts. That men have long thought on this subject and that nations by the trial of actual cases and by the work of the Hague Conferences have made progress towards a permanent and comprehensive juridical organization, is already made plain. Much remains to be done to institute and put into operation the International Prize Court and the Court of Arbitral Justice, which mark the farthest progress that has yet been reached by the whole com- 
munity of nations. May this progress be accelerated by the Third Hague Conference at The Hague.

\section{General Note.}

The student who desires to pursue the subject further, will find help in Darby's "International Tribunals", Moore's "International Arbitrations", and Lorimer's "Institutes of the Law of Nations", especially Volume 2, for matter supplementary to that which is found in Dr. Darby's work.

See also James Brown Scott, "The Hague Peace Conferences, 1899 and 1907"; "Texts of the Peace Conferences at The Hague, 1899 and 1907"; Higgins, "The Hague Peace Conferences"; Holls, "The Peace Conference at The Hague", and similar works. The subject of an international court is treated fully in the reports of the American Society for Judicial Settlement of International Disputes, in the "American Journal of International Law", and in the "Proceedings" of the American Society of International Law. For documents see also the Supplement to the Journal. Back numbers of the Yar.e Law Journal from 1910 furnish a series of articles by the present writer on the work of the Hague court and conferences. These contain more extended explanations of the projects for courts adopted at The Hague, than are found in this article, which is intended as a general survey.

"Arbitral Law and Procedure", by Jackson H. Ralston, is an authoritative work on its subject. For literature on world organization, see Dr. David Jayne Hill's "World Organization", which is a treatment of the subject from the juridical point of view; Raymond L. Bridgman's "World Organization", and "The First Book of World Law"; also Trueblood's "Federation of the World".

No student of this subject should fail to see Scott's American Addresses at the Second Hague Peace Conference, which deals extensively with projects of the new courts. The instructions of Honorable Elihu Root to the American delegates to the Second Hague Conference and the speech by him on "The American Sentiment of Humanity", in the Proceedings of the National Arbitration and Peace Congress, 1907, may be considered as the foundation documents of the Court of Arbitral Justice, of which Mr. Root and Dr. Scott are both recognized as great American exponents. Honorable Andrew D. White's The First Hague Conference 
and Honorable Joseph $\mathrm{H}$. Choate's The Two Hague Conferences ought also to be seen. Articles by Professor Walther Schücking and Jarousse de Sillac in G. Spiller's Inter-Racial Problems, are valuable for their analysis.

Le Palais de la Paix, an illustrated book published at. The Hague by "Vrede Door Recht", the Dutch Peace Society, describes the Palace of Peace, the magnificent gift of Mr. Carnegie, and contains the letter by Dr. Lohman, already referred to, as well as communications by leading pacifists of the day.

For a discussion of international police by Professor C. Van Vollenhoven of Leyden University and the present writer, see Bulletin Officiel du XXme Congrès Universel de la Paix, La Haye, 1913.

Boston, Mass.

James L. Tryon. 